\title{
VARIABILITY OF FILTRATION AND FOOD ASSIMILATION RATES, RESPIRATORY ACTIVITY AND MULTIXENOBIOTIC RESISTANCE (MXR) MECHANISM IN THE MUSSEL Perna perna UNDER LEAD INFLUENCE
}

\author{
PESSATTI, M. L., ${ }^{1}$ RESGALLA JR., C., ${ }^{1}$ REIS Fo., R. W., ${ }^{1}$ KUEHN, J., ${ }^{1}$ \\ SALOMÃO, L. C. ${ }^{2}$ and FONTANA, J. D. ${ }^{3}$ \\ ${ }^{1}$ CTTMar/UNIVALI, C. P. 360, CEP 88302-202, Itajaí, SC, Brazil \\ ${ }^{2}$ Instituto de Biociências, USP, São Paulo, SP, Brazil \\ ${ }^{3}$ LQBB/Departamento de Bioquímica, UFPR, Curitiba, PR, Brazil \\ Correspondence to: Marcos Luiz Pessatti, CTTMar/UNIVALI, C. P. 360, \\ CEP 88302-202, Itajaí, SC, Brazil, e-mail: pessatti@cttmar.univali.br \\ Received August 20, 2001 - Accepted October 9, 2001 - Distributed November 30, 2002
}

(With 1 figure)

\begin{abstract}
The economic importance that myticulture is conquering in Santa Catarina State (South of Brazil) explains the crescent search for new coastal sites for farming. Physiological and biochemical studies of the mussel Perna perna are important to the establishment of methodologies for program assessment and environmental monitoring, allowing to infer about site quality and possible influences of xenobiotic agents on coastal areas. In order to evaluate effects caused by lead poisoning (1.21 $\mu$ mol. $\left.\mathrm{L}^{-1}\right)$, the mussels were maintained at constant temperature $\left(25^{\circ} \mathrm{C}\right)$ and fed with Chaetoceros gracilis for 15 days. The control group was acclimatized in sea water $30 \%$. At the end of this period time, physiological measurements were carried out along with statistic analysis for filtration rates, lead assimilation and overall respiratory activity. The mechanism of multixenobiotic resistance (MXR) was particularly evaluated in standardized gill fragments using rhodamine B accumulation and its quantification under fluorescence optical microscopy. Regarding the control group, results had shown that the mussels maintenance in a lead-poisoned environment caused higher filtration rates (1.04 and 2.3 and L.h $\left.\mathrm{h}^{-1} \cdot \mathrm{g}^{-1} ; \mathrm{p}<0.05\right)$ and lower assimilation rates $(71.96 \%$ and $54.1 \%$, respectively). Also it was confirmed a lesser rhodamine B accumulation in the assays under influence of lead, suggesting that this metal induces the MXR mechanism expression in mussel P. perna. These results indicate that such physiological and biochemical alterations in the mussels can modify the energy fluxes of its metabolism, resulting in possible problems on the coastal systems used as cultivating sites.
\end{abstract}

Key words: physiological parameters, multixenobiotic resistance mechanism, MXR, Perna perna, lead.

\section{RESUMO}

Variabilidade das taxas de filtração, assimilação e respiração e do mecanismo de resistência a multixenobióticos (MXR) no mexilhão Perna perna sob influência do chumbo

A importância sócio-econômica que a mitilicultura conquistou no Estado de Santa Catarina explica a crescente procura por novos sítios costeiros para o seu uso. Estudos fisiológicos e bioquímicos do mexilhão Perna perna se apresentam como metodologias viáveis para programas de avaliação e monitoramento ambiental, permitindo inferir sobre a qualidade dos sítios e possíveis influências de agentes xenobióticos nas áreas costeiras. Com o objetivo de determinar a existência de variabilidade nesses parâmetros evocada pelo chumbo $\left(1.21 \mu \mathrm{mol} . \mathrm{L}^{-1}\right)$, mexilhões Perna perna foram mantidos à temperatura constante e alimentados com Chaetoceros gracilis por 15 dias. O grupo controle foi aclimatado em água do mar a 30\%o. No final desse período foram realizados experimentos estáticos fisiológicos de filtração, respiração e assimilação, 
como também foi quantificada a atividade do mecanismo MXR em fragmentos de brânquias, pelo acúmulo de rodamina $\mathrm{B}$, por microscopia óptica de fluorescência. Em relação ao grupo controle, a manutenção dos organismos em solução de chumbo causou maiores taxas de filtração $\left(1,04\right.$ e 2,3 e L.h $\left.h^{-1} \cdot g^{-1} ; p<0,05\right)$ e menores taxas de assimilação (71,96 e 54,1\%, respectivamente). Também foi confirmado menor acúmulo de rodamina nos organismos sob influência do chumbo, sugerindo que este metal induz a expressão do mecanismo MXR no mexilhão Perna perna. Os resultados indicam que tais alterações fisiológicas e bioquímicas do mexilhão podem alterar os fluxos de energia no metabolismo, resultando em possíveis problemas nos sistemas costeiros utilizados como sítios de cultivos.

Palavras-chave: parâmetros fisiológicos, mecanismo de resistência à multixenobióticos, MXR, Perna perna, chumbo.

\section{INTRODUCTION}

The use of native bivalves in toxicity tests and analysis of environmental quality has been worldwide adopted (EPA, 1989). Mytilides are specially indicated as models for such a purpose due to their sessile behavior, wide distribution and, principally, due to their capacity of bioconcentrating different xenobiotics present in coastal waters (Dame, 1996).

The mussel Perna perna is the most common mytilide exploited and grown in the Brazilian seacoast. The decrease of the traditional fishery allied to $P$. perna nutritive value has favored mussel farming in the last years (Franco, 1993). Southern Brazil, particularly the coastal areas of Santa Catarina state have ranked first in mussel producing countries.

However, diagnosis of environmental quality for the establishment of new areas of myticulture as well as for those that have already been established, has not been properly carried out until present days. Recently, the State Secretary of Environmental Planning (SEPLAM) attached to the Secretary for the Environment (FATMA) together with several universities have engaged in the organization and the design of this activity.

Studies in coastal oceanography, trace elementsbased seawater chemical composition, and biological productivity in farm areas have been recently carried out as well as surveys on whole production, processing, and mussel commercialization. Despite these efforts, little has been done to utilize the P. perna as a bioindicator organism for the environmental conditions and seawater quality.

One of the potential methods for this particular purpose is the determination of multixenobiotic resistance (MXR) mechanism, a parameter analogous for the better known multidrug resistance (MDR) mechanism in mammal cells. The latter phenomenon is a consequence of the expression and/ or activity of a membrane glycoprotein, entitled Pglycoprotein, which effluxes toxic compounds outside the cell in an energy-dependent manner (Riordan \& Ling, 1979; Horio et al., 1988; Kurelec \& Pivcevic, 1989). This mechanism can be induced by contaminated environments, a feature which renders it as a very useful exposition bioindicator (Kurelec et al., 1996).

The variation in physiological rates of filtration, respiration and assimilation in mytilides are equally utilized in the analysis of environmental stress gradients (EPA, 1989). They are usually associated with sub-lethal effects like the alteration of energy distribution in the metabolism of invertebrate organisms (Widdows \& Johnson, 1988).

This study has been conducted in order to evaluate the variability of physiological parameters and of the MXR mechanism in the mussel Perna perna under lead influence, as well as possible interactions among these measurements.

\section{MATERIAL AND METHODS}

\section{Animals}

Batches of ten mussels (Perna perna; mean diameter $30 \mathrm{~mm}$, from Penha Experimental Seaculture Station, UNIVALI, SC), were acclimatized in laboratory using a semi-static system consisting of $3 \mathrm{~L}$-glass bottles under aeration (1 $\mathrm{vol} / \mathrm{min}$ ) and a $12 \mathrm{~h}$ photoperiod during 15 days at $20 \pm 2{ }^{\circ} \mathrm{C}$ and under a pertinent salinity level $(30 \%$ ). The animals were fed once daily with the phytoplankton Chaetoceros gracilis. Each mussel population was split into two halves: the control group and the challenged group under the same cultural conditions except for the inclusion of 1.21 $\mu$ mol.L ${ }^{-1}$ of lead (Titrisol-Merck $\left.{ }^{\circledR}\left[\mathrm{Pb}\left(\mathrm{NO}_{3}\right)_{2}\right]\right)$. At 
the end of the experiment the mussels were kept for a $24 \mathrm{~h}$ period in filtrated $(0.5 \mu \mathrm{m})$ seawater.

\section{Determination of filtration rates}

Static tests to establish rates of individual filtration for each mussel in both treatments (control and lead-containing group), were implemented in $1 \mathrm{~L}$ opaque plastic flasks, with $800 \mathrm{ml}$ of test solution (sea water filtrated with phytoplakton culture). Three control-flasks were assembled to perform corrections in the estimation of phytoplankton density. At the beginning and at end of each 1 hour assay, aliquots of $50 \mathrm{ml}$ of water were taken from test-flasks and the absorbance determinated in spectrophotometer Shimadzu (model UV-160A) at $750 \mathrm{~nm}$ (Bayne \& Newell, 1983). The variation between readings allowed the estimate of filtration rates, expressed in L.h ${ }^{1} \cdot \mathrm{g}^{-1}$. The dry matter inside the organism tissues in each test-flask was determined after 24 hours in a $60^{\circ} \mathrm{C}$ oven or until constant weight.

\section{Determination of respiratory rates}

The respiratory rates were estimated three hours after each filtration assay, according to Widdows \& Johnson (1988). A digital oxymeter (YSI, model 58) was sequentially inserted through a tight orifice in the lid in triplicate test-flasks (1 L) filled with sea water, phytoplankton culture, and mussels to obtain the initial and final readings. Controls were carried out in similar flasks with neither mussels nor phytoplancton and absolute control from flasks with no live species. Respiratory rates were related to mussels biomass and expressed as $\mathrm{ml}$ of $\mathrm{O}_{2} \cdot \mathrm{h}^{-1} \cdot \mathrm{g}^{-1}$.

\section{Determination of assimilation rates}

For the determination of assimilation rates, the same mussels were adapted in test-flasks for an additional period of $24 \mathrm{~h}$ under a reinforced diet of phytoplankton in order to yield a larger amount of feces.

At end of this time, feces produced in each replicate were collected with droppers in filters of glass fiber $(\mathrm{GF} / \mathrm{F})$, freed of salts (Strickland \& Parsons, 1972), and kept frozen at $-20^{\circ} \mathrm{C}$ for subsequent analyses. The same routine was also applied for the phytoplankton given as food. Dry weights were obtained at $60^{\circ} \mathrm{C}$ for $24 \mathrm{~h}$ and the residual mass (ashes) after combustion in a oven at $500^{\circ} \mathrm{C}$ for 2 hours for the inorganic mass subtraction step. Rates of assimilation were recorded as the difference between the dry weights of given organic food content (phytoplankton) and produced feces (Parsons et al., 1984).

\section{Assay of rhodamine B transport}

Rhodamine B accumulation was performed with minor modifications of a previous published method (Cornwall et al., 1995). Three mussels of each treatment were carefully dissected and the gills were collected in filtrated sea water. Small sections $\left(2.5 \mathrm{~mm}^{2}\right)$ were cut from the dorsal edges of the descending arms of each lamella, above the interlamellar tissue bridges, and incubated in sea water with aeration during 20 minutes for mucus removal. Each gill section was incubated with 2 $\mathrm{ml}$ of $1 \mu \mathrm{M}$ rhodamine $\mathrm{B}$ in sea water, for 15 minutes at $16^{\circ} \mathrm{C}$, followed by a 20 sec-rinse with seawater in order to discard any extracellular residual dye. Each executed piece was then assembled on a microscope plate. The fluorescence intensity of the abfrontal side of each gill filament was measured in an epifluorescence microscope Olympus BX60 equiped with U-MWG filter (appropriated for rhodamine) in field with closed diaphragm. The fluorescence emission from the stained tissue was quantified by a coupled photosensor Olympus PM20 regulated at ISO 100 and with a 4.0 exposition adjustment (maximum sensitivity). Control for the basal fluorescence were obtained from gill sections incubated in the absence of rhodamine. Fluorescence arising from fifteen at thirty filaments from each gill section was recorded.

The accumulation of rhodamine $B$ in the presence of verapamil and sodium azide, inhibitors of MXR mechanism, were also measured for the control and lead-challenged mussels.

Fluorescence measurements were proceeded until 10 minutes after the dye excess was washed off and expressed as means and standard deviations. Final results were expressed as the rhodamine B accumulation (nmol. $\mathrm{L}^{-1}$ ) in the gill tissue, using a previous standardization (Pessatti \& Fontana, in prep.).

Mann-Whitney test analyses (Zar, 1984) were conducted to confirm the observed differences in the studied parameters of mussel physiology. 


\section{RESULTS AND DISCUSSION}

One of the largest problems in the use and management of the mussel Perna perna as bioindicator in monitoring studies for environmental quality assessment, is the sexual activity attained soon after its transport to laboratory and/or in the time course of its acclimatization or experiment period. This undesirable situation, was minimized by selecting younger and more immature specimens (30 mm shell diameter).

The results of physiological assays of filtration and assimilation rates of Perna perna are shown in Table 1. A significant difference ( $p<0.05$ and $\mathrm{p}<0.01$, respectively) was found between the control and lead-affected mussels. Opposite effects were obtained in larger filtration rates and smaller assimilation rates as a net consequence of the employed dose of heavy metal. Also a tendency for greater respiration rates was suggested, although it could not be confirmed statistically.

These results suggested that the adverse effect of lead had induced compensatory changes in behavior and in the energetic distribution of mussel metabolic activity. A decrease in the efficiency of food assimilation would have generated an inner energetic deficit for the organism. The compensatory physiological action was therefore an increased filtration rate as an attempt to gather more food. This mechanism has been also observed in other bivalve molluscs under heavy metal-pollution (Dame, 1996).

Regarding the MXR mechanism, the treatment with lead decreased the accumulation of rhodamine (see Fig. 1), suggesting that this heavy metal had increased the expression of MXR mechanism in an analogous manner at previously reported human kidney cells expressing a MDR when confronted with arsenicals and cadmiun (Chin et al., 1990). In this study the regulation of $m d r$ gene expression by those factors were observed.

The expression of $m d r l$ gene (mRNA) has been verified in sponges as well as the correspondent polypeptide P-glycoprotein (Kurelec et al., 1992). Nervertheless the regulation of $m d r$ gene expression is not well known, a possible effect of lead regarding this phenomenon arouses a new approach for this question, which is under investigation due to the possibility of this gene expression in the mussel Perna perna also to be controled, as an answer to environmental exposition to xenobiotics (e.g., lead salts).

In order to assess the effect of cell energy depletion above rhodamine efflux by P-glycoprotein, sodium azide $10 \mathrm{mM}$ in rhodamine solution where gills were incubated was added. Although there was a clear net effect of sodium azide on the rhodamine accumulation, the induction or enhancement of MXR mechanism by lead exposition ended up eliminated when there was a combined exposition to azide and lead, as shown by the same rhodamine B accumulation in relation to sodium azide alone (see Fig. 1). Sodium azide is an efficient blocker of the mytochondrial respiratory chain cytochrome complex and hence of the generation of the coupled oxidative phosphorylation which generates ATP. P-glycoprotein action in turn, due to the association of an ATPase activity, occurs by means of an energy-dependent mechanism (Horio et al., 1988) and could be negatively affected by the presence of azide thus abolishing the MXR mechanism launched by lead as revelead by a lower rhodamine accumulation (see Fig. 1).

Also the effect of verapamil, a competitive inhibitor of P-glycoprotein was examined, thereby inhibiting the drug pump activity and therefore the rhodamine B efflux being promoted by P-glycoprotein. As shown in Fig. 1, verapamil $0.1 \mu \mathrm{M}$ increased the rhodamine $\mathrm{B}$ accumulation in the same ratio as sodium azide $10 \mathrm{mM}$. Considering the specificity of this inhibitor, these data are strongly suggestive, as expected, of a MXR mechanism.

There are several detoxification mechanisms utilized by the organisms like bivalves due to their permanent exposition to open environments (sea water). If one assumes that lead is not acting as a chemosensitizer by itself, the physiological reaction of the lead-intoxicated mussel as revealed by higher filtration rates and lower food assimilation rates, could be connected also to the induction of expression or, at least, to enhancement of an alternative defense mechanism like MXR, which is known to be mediated by P-glycoprotein.

The gills of bivalves are considered the entry door for all substances present in the marine liquid environment and hence a primary detoxification is expected to be active in the same tissue of the mussel. The animal feeding strategy simply consists in water pumping across the gills, where particles in suspension (organic matter and phytoplanckton) are retained due to the mucus secretion. 


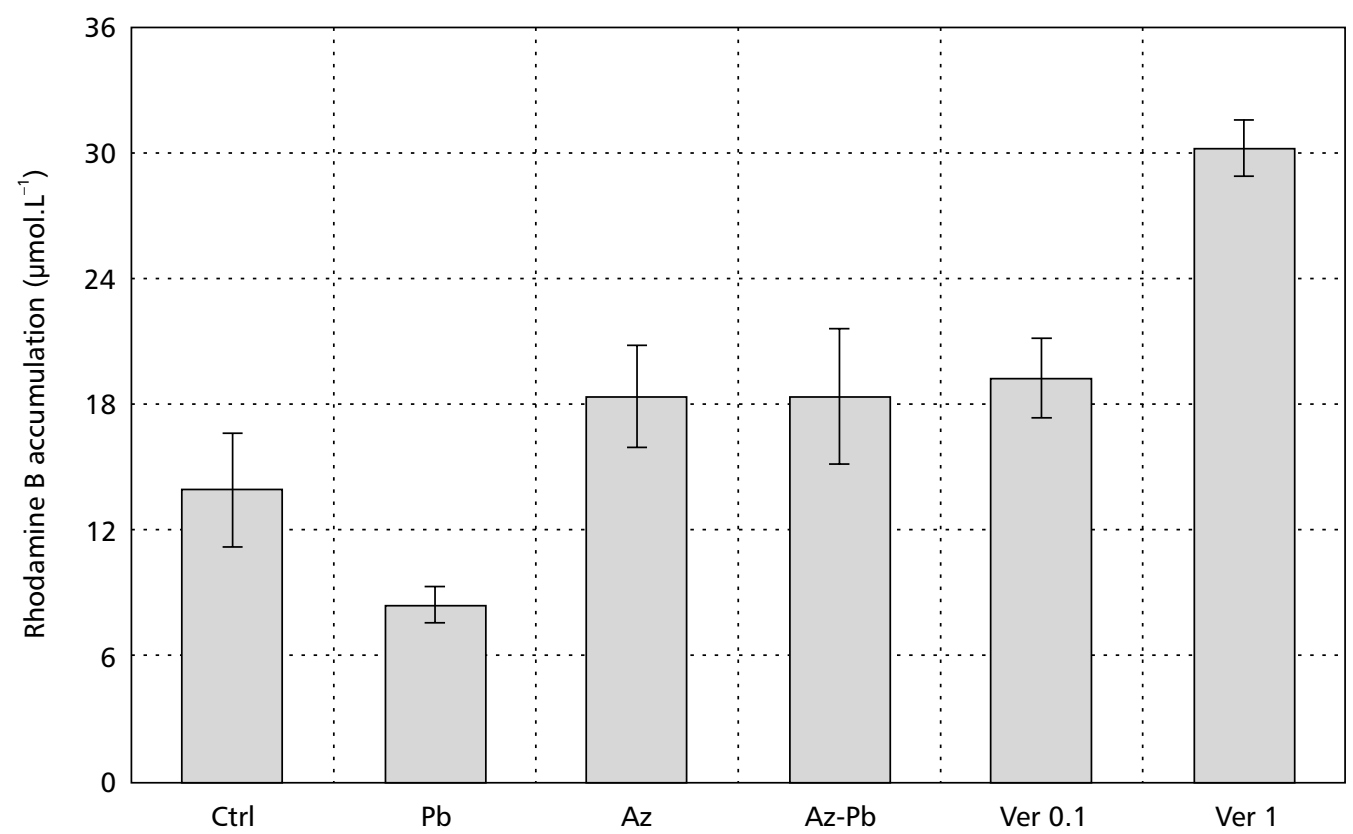

Fig. 1 - Lead nitrate $1.21 \mu \mathrm{mol} . \mathrm{L}^{-1}(\mathrm{~Pb})$, sodium azide $10 \mathrm{mM}(\mathrm{Az})$ and verapamil 0.1 and $1 \mu \mathrm{mol} . \mathrm{L}^{-1}$ (Ver 0.1 and Ver 1 , respectively) effects on rhodamine B accumulation in isolated gills of the Perna perna. Data shown are means $\pm \mathrm{SME}$ (confidence interval, $\mathrm{p}<0.05)$ and are indicated as rhodamine $\mathrm{B}$ accumulation $\left(\mathrm{nmol} \cdot \mathrm{L}^{-1}\right)$. Ctrl $=$ control.

TABLE 1

Results from the physiological assays of filtration, food assimilation, and respiration of the mussel Perna perna following the control treatment (sea water) or exposition to lead $\left(1.21 \mu \mathrm{mol} . \mathrm{L}^{-1}\right)$ in sea water.

\begin{tabular}{|l|c|c|c|c|c|c|}
\hline Assays & Treatment & Average & SD & $\mathbf{n}$ & $\mathbf{z}$ & $\mathbf{p}$ \\
\hline $\begin{array}{l}\text { Filtration rate } \\
\left({\mathrm{L} . \mathrm{h}^{-1}}^{-1} \cdot \mathrm{g}^{-1}\right)\end{array}$ & Control & 1.04 & 0.32 & 5 & -2.20 & \\
\cline { 2 - 7 } & Lead & 2.30 & 1.46 & 4 & & $\mathrm{p}<0.05$ \\
\hline $\begin{array}{l}\text { Respiration rate } \\
\left(\mathrm{mlO}_{2} \cdot \mathrm{h}^{-1} \cdot \mathrm{g}^{-1}\right)\end{array}$ & Control & 1.23 & 0.26 & 5 & -1.57 & \\
\cline { 2 - 7 } & Lead & 1.53 & 0.18 & 5 & & $\mathrm{p} \geq 0.05 *$ \\
\hline $\begin{array}{l}\text { Assimilation } \\
\text { rate }(\%)\end{array}$ & Control & 71.96 & 11.10 & 5 & -2.40 & \\
\cline { 2 - 7 } & Lead & 54.10 & 8.89 & 5 & & $\mathrm{p}<0.01$ \\
\hline
\end{tabular}

$\mathrm{SD}=$ Standard Deviation; $\mathrm{n}=$ number of duplicate assays; $\mathrm{z}=$ statistical value;

$\mathrm{p}=$ significant at 0.05 or 0.01 (Mann-Whitney statistical assay); (*) not significant. 
In ecological terms, the physiological alterations herein observed, which can be induced for different xenobiotics in the environment, and not only by heavy metals, could result in a deviation within the energetic metabolism, engaging production, as growth and ripening (EPA, 1989). This larger energy consumption could compromise the support capacity of the animal under this particular environmental impact, since more, often, less food is available in excess (Abel \& Axiak, 1991). Alternatively, this reaction strategy could provide an advantage within the competition process with other filter-bearing organisms in the same environment.

Concerning environmental quality, increased filtration rates associated to decreased food assimilation contribute to increase sedimentation rate of suspended material in pellet-shaped feces (Schettini et al., 1997). Furthermore, these enriched feces promote the accumulation of organic matter in the sea bottom, generating an anoxyc condition in sediment with a consequent decrease of local animal diversity, increasing the bacterial proliferation. Moreover, these feces, rich in xenobiotics as result of lowered food assimilation and/or activation of a MXR detoxification mechanism, can be a source of contamination to benthic and pelagic systems of the cultivated areas.

However, detailed quantitative studies of such processes, ecological modeling of involved rates and the knowledge of the dynamics of water and the processes of bottom resuspension are necessary to evaluate the risk time in environments under different levels of impact.

Acknowledgments - The authors are thankful to Valéria $\mathrm{R}$. Bellotto and Isabel Pellens for help with the mussel support, CAPES - National Council for Scientific and Technological Development for the Ph.D. fellowship support and UNIVALI - Itajaí Valley University for funding provision.

\section{REFERENCES}

ABEL, P. D. \& AXIAK, V., 1991, Ecotoxicology and the Marine Environment. ELLIS HORWOOD, New York, $265 \mathrm{p}$.

BAYNE, B. C. \& NEWELL, R. C., 1983, Physiological energetics of marine molluscs, pp. 407-515. In: A. S. M. Saleuddin \& K. M. Wilbur (eds.), The mollusca. Vol. 4, Academic Press, New York.

CHIN, K. V., TANAKA, S., DARLINGTON, G., PASTAN, I. \& GOTTESMAN, M. M., 1990, Heat-shock and arsenite increase expression of the multidrug resistance ( $m d r l)$ gene in human carcinoma cells. J. Biol. Chem., 265: $221-226$
CORNWALL, R., TOOMEY, B. H., BARD, S., BACON, C., JARMAN, W. M. \& EPEL, D., 1995, Characterization of multixenobiotic/multidrug transport in the gills of the mussel Mytilus californianus and identification of environmental substrates. Aquat. Toxicol., 31: 277-296.

DAME, R. F., 1996, Ecology of marine bivalves - an ecosystem approach. CRC PRESS, Boca Raton, 254p.

EPA, 1989, Biomonitoring for control of toxicity in effluent discharges to the marine environment. EPA 625 8-89 015, Cincinnati, $57 \mathrm{p}$.

FRANCO, H. M., 1993, Santa Catarina é o maior produtor nacional de mexilhões. Agropecuária Catarinense, 6: 45-48.

HORIO, M., GOTTESMAN, M. M. \& PASTAN, I., 1988, ATP-dependent transport of vinblastine in vesicles from human multidrug-resistance cells. Proc. Natl. Acad. Sci. USA., 85: 3580-3584.

KURELEC, B. \& PIVCEVIC, B., 1989, Distinct glutathionedependent enzyme activities and a verapamil-sensitive binding of xenobiotics in a fresh-water mussel Anodonta cygnea. Biochem. Biophys. Res. Commun., 164: 934-940.

KURELEC, B., KRCA, S., PIVCEVIC, B., UGARKOVIC, D., BACHMANN, M., IMSIECKE, G. \& MUELLER, W. E. G., 1992, Expression of P-glycoprotein gene in marine sponges. Identification and characterization of the $125 \mathrm{kDa}$ drug-binding glycoprotein. Carcinogenesis., 13: 69-76.

KURELEC, B., KRCA, S. \& LUCIC, D., 1996, Expression of multixenobiotic resistance mechanism in a marine mussel Mytilus galloprovincialis as a biomarker of exposure to polluted environments. Comp. Biochem. Physiol., 113C: 283-289.

PARSONS, T. R., TAKAHASHI, M. \& HARGRAVE, B., 1984, Biological Oceanographic Processes. PERGAMON PRESS, Oxford, 330p.

PESSATTI, M. L. \& FONTANA, J. D. Multixenobiotics resistance mechanism in mussel $P$. perna: standardization of fluorescence emmited by rhodamine B. In preparation.

RIORDAN, J. R. \& LING, V., 1979, Purification of pglicoprotein from plasma membrane vesicles of chinese hamster ovary cell mutants with reduced colchicine permeability. J. Biol. Chem., 254: 12701-12705.

SCHETTINI, C. A. F., RESGALLA Jr., C. \& KUROSHIMA, K. N., 1997, Avaliação preliminar da taxa de sedimentação na região de cultivo de moluscos (Perna perna) na enseada da Armação, SC. Notas Técnicas da FACIMAR, 1: $1-7$.

STRICKLAND, J. D. H. \& PARSONS, T. R., 1972, A practical handbook of seawater analysis. Fishery Research Board, Canada, 310p.

WIDDOWS, J. \& JOHNSON, D., 1988, Physiological energetics of Mytilus edulis: scope for growth. Mar. Ecol. Prog. Ser., 46: 113-121.

ZAR, J. H., 1984, Biostatistical Analysis. Prentice-Hall, New Jersey, $2^{\text {th }}$ ed., 718 p. 